\title{
Studi Numerik Performa Rangka Bresing Eksentrik Link Vertikal Profil Tubular
}

\author{
Dzul Fikri Muhammad ${ }^{1, *}$, Budi Suswanto ${ }^{1}$ \\ Departemen Teknik Sipil, Insitut Teknologi Sepuluh Nopember, Surabaya ${ }^{1}$ \\ Koresponden*, Email: dzulfikrimuhammad@gmail.com
}

\begin{tabular}{lr}
\hline & Info Artikel \\
\hline Diajukan & 4 Desember 2019 \\
Diperbaiki & 30 Januari 2020 \\
Disetujui & 30 Januari 2020
\end{tabular}

Keywords: eccentrically braced frame, earthquake rehabilitation, finite element method, hysteresis curve
Kata kunci: rangka bresing eksentrik, rehabilitasi gempa, metode elemen hingga, kurva histeresis

\begin{abstract}
Eccentrically Braced Frames (EBF) have been used as earthquake suppression systems, especially in buildings. This system relies on yielding at link. EBF with horizontal link has important weaknesses to review. In the event of an earthquake that causes the link beam to rotate vertically, causing the structure above the beam damaged. Also it is not easy to repair the beam link at H-EBF after a severe earthquake. To overcome the problems in the H-EBF system, a new system was proposed, called Vertical-EBF (V-EBF). Links with WF and tubular profiles are two profiles commonly used in structures. In this research, EBF specimen modeling with tubular profile vertical links was compared with EBF horizontal links. The results showed a structure with V-EBF had a lighter weight. Yielding only occur at link so its better for earthquake rehabilitation.
\end{abstract}

Abstrak

Eccentrically Braced Frames (EBF) telah digunakan sebagai sistem penahan beban gempa, terutama pada bangunan gedung. Sistem ini mengandalkan pada lelehnya link terlebih dahulu. EBF dengan link horizontal (H-EBF) memiliki kelemahan yang penting untuk ditinjau. Pada saat terjadi gempa bumi yang menyebabkan link balok akan memutar secara vertikal sehingga menyebabkan struktur diatas balok akan rusak. Selain itu tidak mudah memperbaiki link balok di H-EBF setelah gempa bumi yang parah. Untuk mengatasi masalah dalam sistem H-EBF, terdapat sistem yang telah diusulkan, disebut Vertikal-EBF (V-EBF). Link dengan profil WF dan tubular adalah dua profil yang biasa digunakan pada struktur. Pada penelitian ini dilakukan pemodelan spesimen EBF link horizontal dibandingkan dengan EBF dengan link vertikal berprofil tubular. Hasil penelitian menunjukkan struktur dengan V-EBF memiliki berat lebih ringan. Pelelehan pada V-EBF hanya terjadi pada bagian link sehingga lebih baik dalam rehabilitasi gempa.

\section{Pendahuluan}

Eccentrically Btaced Frame (EBF) telah digunakan sebagai sistem penahan gempa, terutama pada bangunan gedung[1]. Sistem ini telah terbukti memberikan daktilitas dan disipasi energi yang baik pada gempa dan perilakunya telah diteliti[2]. Saat terjadi beban gempa, link pada EBF akan berfungsi sebagai sekring daktail, berotasi plastis sementara komponen struktur lain akan tetap elastis[3],[4]. Sistem ini menyediakan kekakuan seperti rangka bresing konsentrik (CBF) dan juga memiliki daya serap energi seperti rangka penahan momen (MRF)[5], Sehingga sistem ini bisa disebut dengan sistem hybrid. Terdapat 3 tipe link yaitu link geser, menengah, dan lentur[6]. Link geser lebih stabil dan daktail [7],[8]. Perilaku histeresis yang sangat baik dari Eccentrically Braced Frames (EBF) menggunakan link geser telah menjadi sistem alternatif yang efektif daripada sistem rangka penahan momen maupun struktur rangka bresing konsentris[9]. Namun pola keruntuhan pada rangka bresing eksentrik yang mengandalkan link horizontal (H-EBF) pada umumnya akan merusak struktur yang berada diatasnya seperti digambarkan pada pola keruntuhan menurut Bosco dan Rossi[10] seperti terlihat pada Gambar 1.

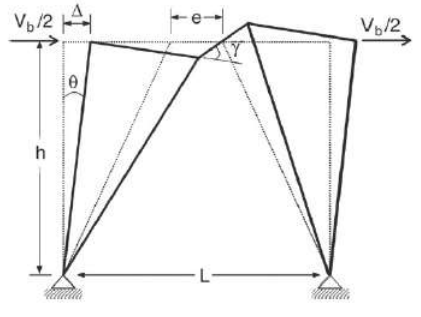

Gambar 1. Pola Keruntuhan EBF dengan Link Horizontal Sumber: Bosco dan Rossi[10]

Struktur yang sensitif seperti pembangkit listrik memerlukan struktur yang tetap berada di tempatnya agar tetap berfungsi dengan baik [9]. Sehingga pola keruntuhan H-EBF tidak memungkinkan dalam rehabilitasi gempa untuk struktur ini. Sistem rangka bresing eksentrik dengan link vertikal (V-EBF) memiliki keruntuhan yang berbeda dengan H-EBF menurut Gambar 2 pada penelitian Rosario [11] pada tahun 2014. Dalam sistem ini, bresing berbentuk 
V terbalik melekat pada balok lantai melalui panel geser. Deformasi inelastik intensif hanya terjadi di panel geser dan energi internal diserap oleh bagian ini[9].
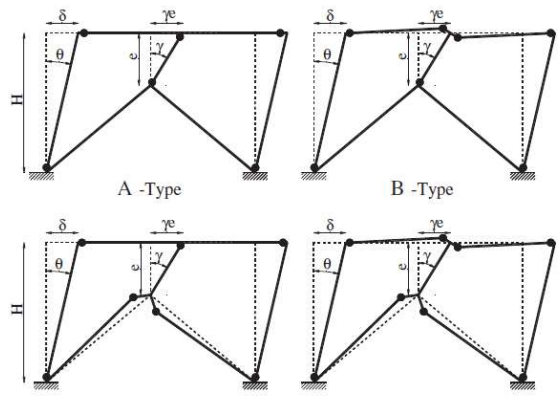

C -Type

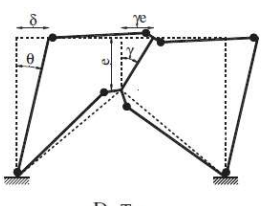

D -Type

Gambar 2. Mode Kegagalan frame V-EBF[11]

Sumber: Montouri dkk. [11]

Montuori dkk [11]melakukan analisa Push Over pada portal rangka bresing eksentrik dengan link vertical seperti terlihat pada Gambar 3. Pada penelitian ini memakai rumus panjang link yaitu

$\mathrm{e}=1.6 \mathrm{M}_{\mathrm{p}} / \mathrm{V}_{\mathrm{p}}$

dimana:

$M_{p} \quad=$ Kapasitas Momen Plastis

$V_{p} \quad=$ Kapasitas Geser Plastis

e $\quad=$ Panjang Link

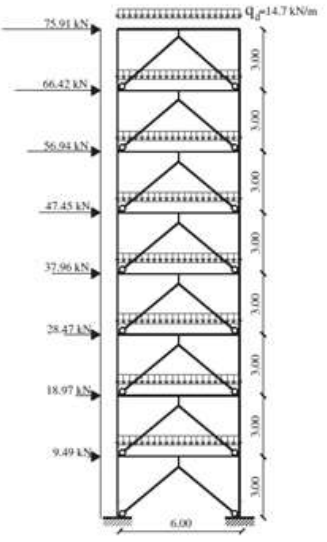

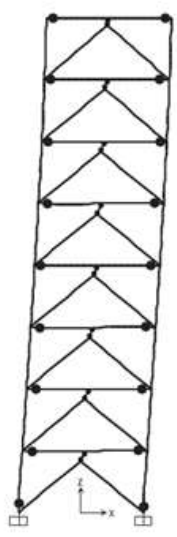

b.
Gambar 3. Mode Kegagalan Portal V-EBF[2]

Sumber: Bowkamp dkk. 2016

Pada penelitian ini diturunkan rumus panjang link untuk link geser vertikal, yaitu:

$e \leq \frac{2 \times 1.2 M_{p}}{2 V_{p}}=1.2 \frac{M_{p}}{V_{p}}$ dimana:

$M_{p} \quad=$ Kapasitas Momen Plastis

$V_{p} \quad=$ Kapasitas Geser Plastis

e $\quad=$ Panjang Link

Selain itu Bowkamp[2] menyimpulkan bahwa V-EBF terindikasi sebagai sistem daktail dengan rasio daktilitas tinggi dan dapat mendisipasi energi dengan grafik hysteresis yang stabil tanpa pinching sampai terjadi kegagalan (Gambar 4).

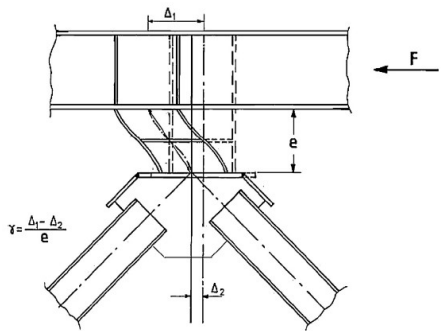

Gambar 4 . Leleh pada Link V-EBF [2]

Sumber: Bowkamp dkk., [2]

Suswanto[12] pada tahun 2018 melakukan penelitian perbandingan link dengan profil WF dan profil tubular. Link dengan profil tubular mempunyai nilai daktilitas yang lebih baik daripada link dengan profil WF[12]. Link dengan panjang melebihi batas ketentuan link pendek atau link geser tidak dapat mencapai gaya geser nominal baik dengan profil WF dan profil tubular[12]. Sehingga dengan link berprofil tubular, link tipe geser tetap lebih baik dalam menahan gaya geser daripada link menengah dan link panjang. Berdasarkan hasil penelitian Suswanto dkk[12]. pada tahun 2018, saat beban rotasi diberikan kepada link pendek, gaya geser pada link WF berkurang rata-rata $2.75 \%$ setiap langkah, ini terjadi karena tekuk lokal pada WF. Sementara itu, gaya geser pada link tubular lebih stabil saat penambahan beban rotasi siklik, sehingga dapat disimpulkan bahwa link pendek tubular memiliki daktilitas yang lebih baik daripada link WF (Gambar 5). Sehingga perlu dilakukan penelitian untuk mengetahui bagaimana performa link vertikal profil tubular pada struktur rangka bresing eksentrik. Persamaan konstitutif baja tegangan regangan dapat didekati dengan persamaan Mander[13] dalam Rofiq dkk [14].
a. Elastic Loading $\left(0 \leq \varepsilon_{\mathrm{s}} \leq \varepsilon_{\mathrm{y}}\right)$
$\mathrm{f}_{\mathrm{s}}=\mathrm{E}_{\mathrm{s}} \varepsilon_{\mathrm{s}}$
b. Yield Plateu $\left(\varepsilon_{\mathrm{y}} \leq \varepsilon_{\mathrm{s}} \leq \varepsilon_{\mathrm{sh}}\right)$
$\mathrm{f}_{\mathrm{s}}=\mathrm{f}_{\mathrm{y}}$
c. Strain Hardened Curve $\left(\varepsilon_{\mathrm{sh}} \leq \varepsilon_{\mathrm{s}} \leq \varepsilon_{\mathrm{su}}\right)$
$\mathrm{f}_{\mathrm{s}}=\mathrm{f}_{\mathrm{su}}+\left(\mathrm{f}_{\mathrm{y}}-\mathrm{f}_{\mathrm{su}}\right)\left|\frac{\varepsilon_{s u}-\varepsilon_{s}}{\varepsilon_{s u}-\varepsilon_{s h}}\right|^{P}$ 


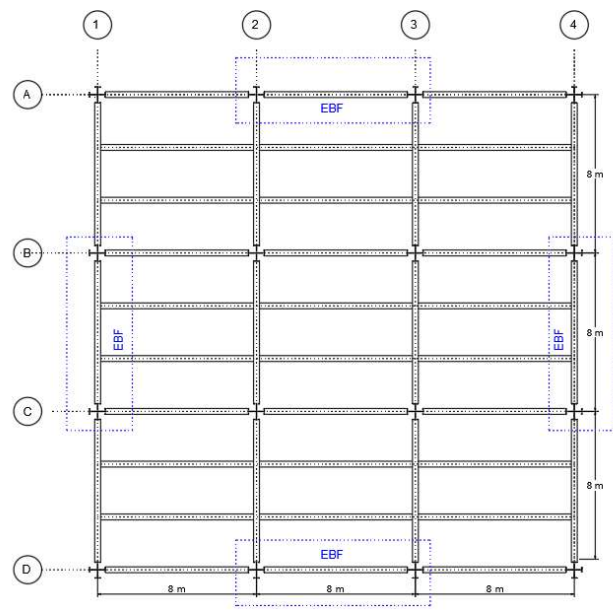

a.

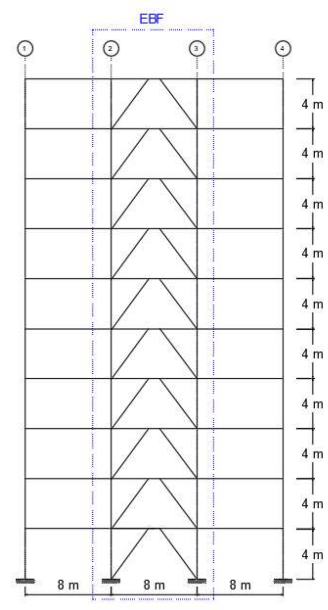

b.

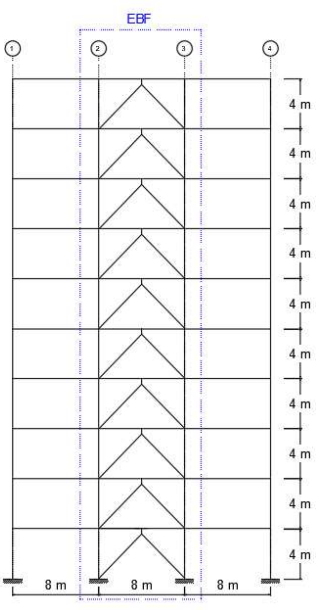

c.

Gambar 5. a. Denah Pemodelan Makro b. Portal Rangka Bresing Eksentrik Link Horizontal c. Portal Rangka Bresing

Sumber: Hasil Analisis

$P=E_{s h}\left(\frac{\varepsilon_{s u}-\varepsilon_{s h}}{f_{y}-f_{s u}}\right)$

Dimana:

$\mathrm{f}_{\mathrm{su}} \quad$ : Tegangan Ultimit Baja

$\mathrm{f}_{\mathrm{y}} \quad$ : Tegangan leleh

$\mathrm{E}_{\mathrm{s}} \quad$ : Modulus elastisitas baja.

$\varepsilon_{\text {sh }} \quad$ : Regangan baja saat awal stain hardening

$\varepsilon_{\mathrm{su}} \quad$ : Regangan baja ultimit

$\mathrm{f}_{\mathrm{s}} \quad$ : Tegangan baja

$\varepsilon_{\mathrm{s}} \quad$ : Regangan baja

\section{Metode}

Pada penelitian ini akan dilakukan analisa metode elemen hingga secara makro dan mikro. Analisa makro
Eksentrik Link Vertikal Profil Tubular

menggunakan gedung dengan tiga portal 3 dimensi berjumlah 10 lantai dengan bentang 8 meter.

Portal rangka bresing eksentrik berada di tengah pada masing-masing portal tepi pada arah $\mathrm{x}$ dan arah y. Link pada pemodelan rangka bresing eksentrik menggunakan link pendek dengan rumus panjang link $\mathrm{e}=1.6 \mathrm{Mp} / \mathrm{Vp}$. Pemodelan yang dilakukan yaitu Rangka Bresing Eksentrik Link Horizontal (H-EBF) dan Rangka Bresing Eksentrik Link Vertikal Profil Tubular (V-EBF) seperti ditunjukkan pada Gambar 5. Model tersebut akan dimodelkan secara 3 dimensi. Pada model tersebut akan menggunakan denah, pembebanan, dan material yang sama. Pada pemodelan ini elemen kolom (K) menggunakan profil King Cross (KC), elemen balok induk (BI) dan balok anak (BA) menggunakan profil Wide Flange (WF), elemen link pada

Tabel 1. Profil Rangka Bresing Eksentrik Link Horizontal (H-EBF)

\begin{tabular}{ccccc}
\hline Lantai & Kolom & Balok & Bresing & Link \\
\hline $\mathbf{1 - 4}$ & KC 800.300.14.26 & WF 488.300.18.11 & WF 488.300.18.11 & WF 488.300.18.11 (e=1.25 m) \\
$\mathbf{5 - 7}$ & KC 588.300.12.20 & WF 390.300.16.10 & WF 390.300.16.10 & WF 390.300.16.10 (e=1.25 m) \\
$\mathbf{8 - 1 0}$ & KC 488.300.11.18 & WF 400.200.13.8 & WF 400.200.13.8 & WF 400.200.13.8 $(\mathrm{e}=1 \mathrm{~m})$ \\
\hline Sumber: Hasil Analisis & & &
\end{tabular}

Tabel 2.Profil Rangka Bresing Eksentrik Link Vertikal Profil Tubular (V-EBF)

\begin{tabular}{ccccc}
\hline Lantai & Kolom & Balok & Bresing & Link \\
\hline $\mathbf{1 - 4}$ & KC 700.300.13.24 & WF600.200.17.11 & WF 600.200.17.11 & RHS 300.200.12.12 $(\mathrm{e}=0.4 \mathrm{~m})$ \\
$\mathbf{5 - 7}$ & KC 588.300.12.20 & WF 450.200.14.9 & WF 450.200.14.9 & RHS 300.200.8.8 (e =0.4 m) \\
$\mathbf{8 - 1 0}$ & KC 488.300.11.18 & WF 400.200.13.8 & WF 400.200.13.8 & RHS 300.200.6.6 (e=0.4 m) \\
\hline
\end{tabular}

Sumber: Hasil Analisis 


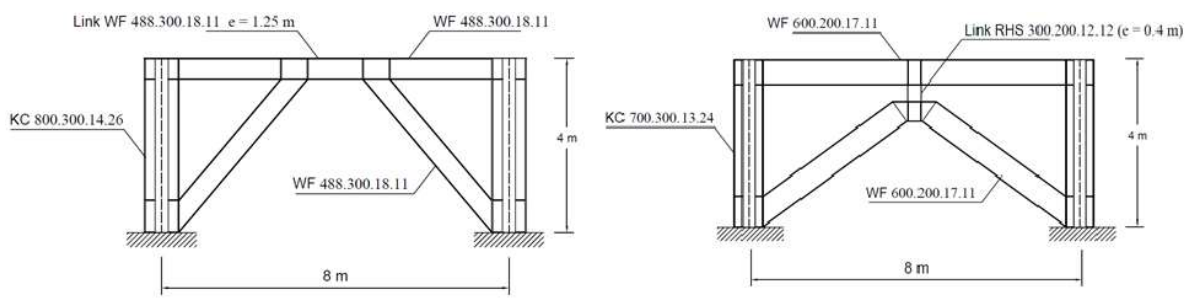

Gambar 6. Portal pemodelan mikro rangka bresing eksentrik a. Link Horizontal b. Link vertikal profil tubular Sumber: Hasil Analisis

EBF Horizontal menggunakan profil Wide Flange (WF), EBF Vertikal menggunakan Rectangular Hollow Section (RHS) dengan profil seperti ditunjukkan pada Tabel 1 dan 2. Seluruh elemen menggunakan BJ $41 f y=250 \mathrm{MPa} f u=$ $410 \mathrm{MPa}$. Pada pemodelan makro akan dilakukan beberapa kontrol yang terdiri dari:

1. Kontrol Partisipasi Massa

2. Kontrol Nilai Akhir Respon Spektrum

3. Kontrol Waktu Getar Alami Fundamental

4. Kontrol Simpangan Antar Lantai

Kemudian selanjutnya dilakukan pengecekan profil dan Push over. Evaluasi hasil permodelan SAP 2000 berisi perbandingan perilaku dari spesimen penelitian. Perbandingan perilaku spesimen terdiri dari:

1. Perpindahan Lateral

2. Simpangan Antar Lantai

3. Perbandingan efisiensi / berat.

Setelah mekanisme runtuh secara global pada pemodelan struktur sesuai dengan metodologi desain, maka dilakukan pemodelan mikro. Pada pemodelan ini akan dimodelkan satu portal seperti pada Gambar 6 dengan ukuran profil sama dengan pemodelan makro pada lantai 1-4 seperti ditunjukkan pada Tabel 3. Pemodelan yang dilakukan yaitu membandingkan perilaku pada $\mathrm{H}-\mathrm{EBF}$ dan V-EBF. Pada pemodelan Abaqus diperlukan beberapa penyesuaian di dalam software antara lain:

\section{Model Geometry}

Model geometri pada kedua pemodelan yaitu satu portal pada lantai bawah dari pemodelan $3 \mathrm{D}$ seluruh rangka. Dengan bentang balok 8 meter dan tinggi kolom 4 meter seperti ditunjukkan pada Gambar 6.

2. Model Meshing
Meshing pada frame dimodelkan dengan tipe C3D8R. ukuran meshing sebesar $100 \mathrm{~mm}$.

3. Material properties

Material yang digunakan adalah BJ 41 dengan $f y=250$

$\mathrm{MPa}$ dan $f u=410 \mathrm{MPa}$. Input pada bagian elastic menggunakan modulus elastisitas sebesar $200000 \mathrm{MPa}$ dan 0.3 untuk nilai poisson ratio. Input pada bagian plastic material menggunakan data $f y$ dan regangan plastis material (Tabel 4).

Tabel 4 . Input material pada pemodelan mikro [15]

\begin{tabular}{lll}
\hline No. & Yield Stress & Plastic Strain \\
\hline 1 & 250 & 0 \\
2 & 251 & 0.015 \\
3 & 345 & 0.04 \\
4 & 410 & 0.1 \\
\hline \multicolumn{3}{l}{ Sumber: Suswanto dkk.[12] }
\end{tabular}

4. Interaction

Sambungan antar elemen struktur dimisalkan dengan sambungan las atau menempel sempurna. Sehingga interaksi antar elemen pemodelan menggunakan tipe tie constraint.

5. Boundary Condition (BC)

Pada dasar kedua kolom menggunakan $\mathrm{BC}$ tipe encastre dan pada kedua kolom bagian atas menggunakan BC tipe displacement. Fungsi BC pada dasar kolom yaitu mengikat seperti jepit pada dasar kolom pada umumnya. Pada BC kolom bagian atas berfungsi sebagai pembebanan AISC Seismic Provision 2010 seperti ditunjukkan pada Gambar 7. Pembebanan dari AISC Seismic Provision 2010 akan dikonversi menjadi displacement. Nilai displacement ini akan menjadi input pada pemodelan mikro.

Tabel 3. Profil Spesimen Pemodelan Mikro

\begin{tabular}{cccccc}
\hline Kode & Jenis EBF & Kolom & Balok & Bresing & Link \\
\hline H-EBF & EBF Link & KC 800.300.14.26 & WF 488.300.18.11 & WF 488.300.18.11 & WF 488.300.18.11 \\
& Horizontal & & & & $(\mathrm{e}=1.25 \mathrm{~m})$ \\
V-EBF & EBF Link Vertikal & KC 700.300.13.24 & WF 600.200.17.11 & WF 600.200.17.11 & $\begin{array}{c}\text { RHS 300.200.12.12 } \\
(\mathrm{e}=0.4 \mathrm{~m})\end{array}$ \\
\hline
\end{tabular}

Sumber: Hasil Analisis 


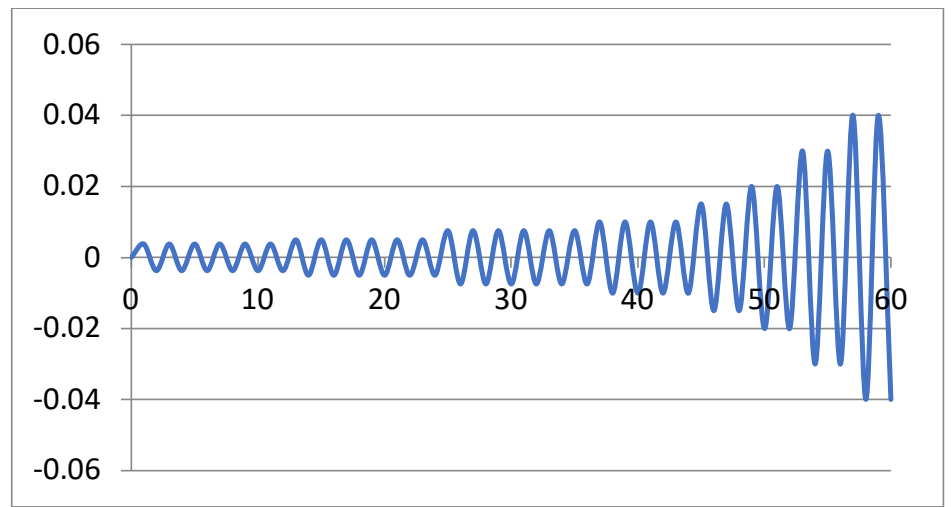

Gambar 7. Pembebanan Pada Pemodelan Mikro[6]

Sumber: AISC 2010 Seismic Provision

\section{Hasil dan Pembahasan}

\section{a. Pemodelan Makro}

Dari Gambar 9 dan 10 dapat dilihat bahwa nilai deformasi lantai arah $\mathrm{x}$ dan arah y pada H-EBF dan V-EBF terlihat saling berhimpit. Sehingga dapat dikatakan deformasi lantai arah x pada kedua pemodelan hampir sama.

Pada Gambar 11 dapat dilihat bahwa nilai deformasi antar lantai arah x pada H-EBF dan V-EBF pada lantai 1,2, dan 6 memiliki nilai yang hampir sama. Pada lantai 3,4, dan 5 H-EBF memiliki nilai lebih besar. Pada lantai 7-atap VEBF memiliki nilai lebih besar.
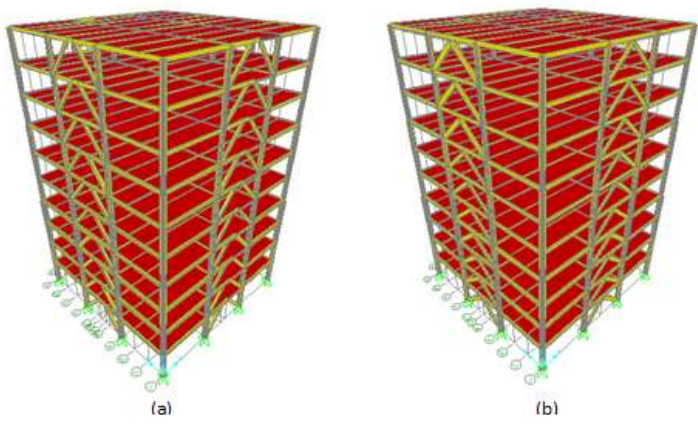

Gambar 8. Pemodelan Makro 3D; a. H-EBF, b. V-EBF Sumber: Hasil Analisis

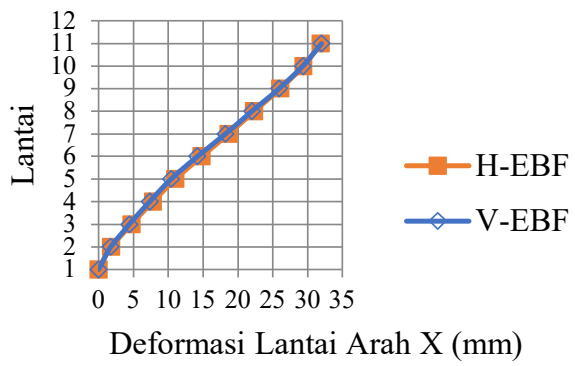

Gambar 9. Perbandingan Deformasi Lantai Arah X Sumber: Hasil Analisis

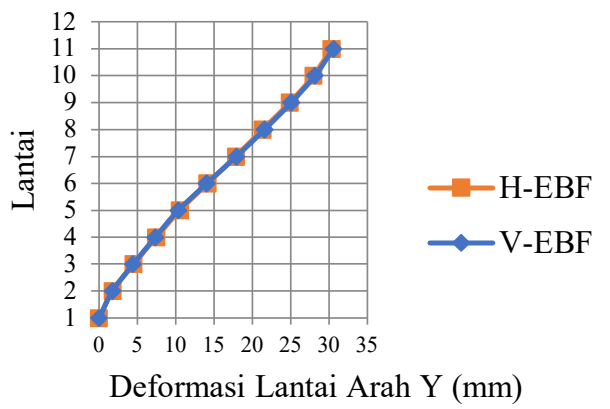

Gambar 10. Perbandingan Deformasi Lantai Arah Y Sumber: Hasil Analisis

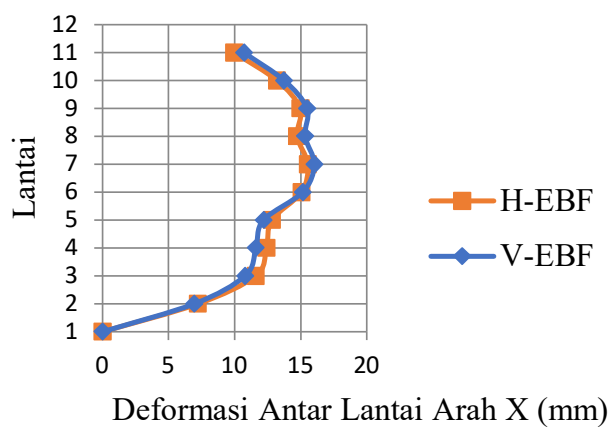

Gambar 11. Perbandingan Deformasi Antar Lantai Arah X Sumber: Hasil Analisis

Pada Gambar 12 dapat dilihat bahawa nilai deformasi antar lantai arah y pada H-EBF dan V-EBF pada lantai 1,2, 9, dan 10 memiliki nilai yang hampir sama. Pada lantai 3,4, dan 5 rangka bresing eksentrik memiliki nilai lebih besar. Pada lantai 6,7,8,9, dan atap V-EBF memiliki nilai lebih besar. 


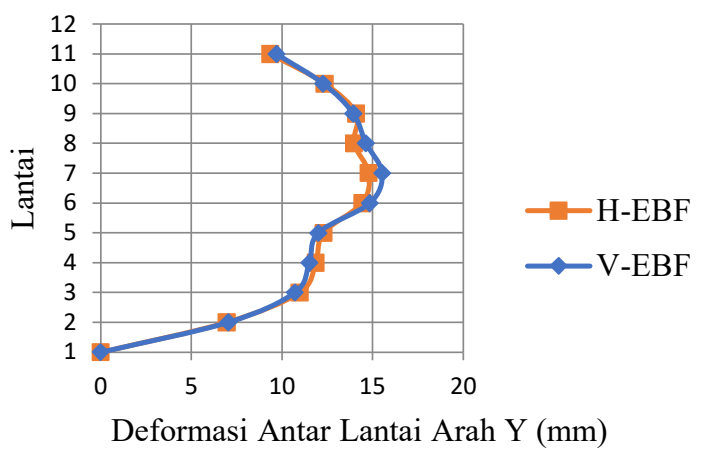

Gambar 12. Perbandingan Deformasi Antar Lantai Arah Y Sumber: Hasil Analisis

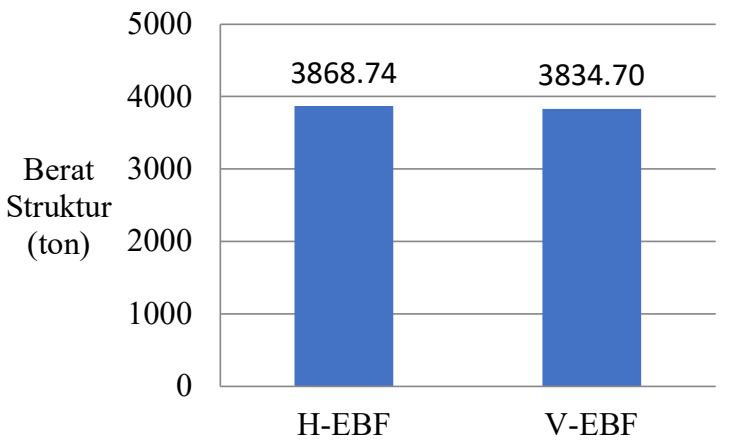

Gambar 13. Perbandingan Berat Struktur H-EBF dan VEBF

Sumber: Hasil Analisis

Pada gambar 13 dapat dilihat bahwa dari hasil pemodelan yang dilakukan, berat struktur pada H-EBF sebesar $3868740.3 \mathrm{Kg}$ dan berat V-EBF didapatkan $3834700.47 \mathrm{Kg}$. Berdasarkan hasil diatas, maka dengan denah struktur, pembebanan, dan material yang sama, VEBF mempunyai berat struktur yang lebih ringan sebesar 34089,83 Kg.

Pada masing-masing pemodelan terdapat kolom berwarna hijau pada lantai 1 . Warna biru pada pemodelan menandakan bahwa profil aman untuk menahan beban yang bekerja pada gedung tersebut. Pada kedua pemodelan terdapat kolom berwarna hijau pada lantai dasar. Pada pemodelan rangka bresing eksentrik profil tubular terdapat balok berwarna hijau pada portal rangka bresing eksentrik pada lantai 2-7.

Pada pemodelan H-EBF pelelehan pertama terjadi di elemen struktur link pada lantai 2. Simpangan pada kolom pada lantai paling atas adalah $121.01 \mathrm{~mm}$. Simpangan antar lantai pada kolom yang terdapat pada frame yang memiliki link leleh di lantai 2 adalah $13 \mathrm{~mm}$. mekanisme runtuh pada pemodelan H-EBF telah memenuhi syarat yaitu leleh pada link terlebih dahulu.

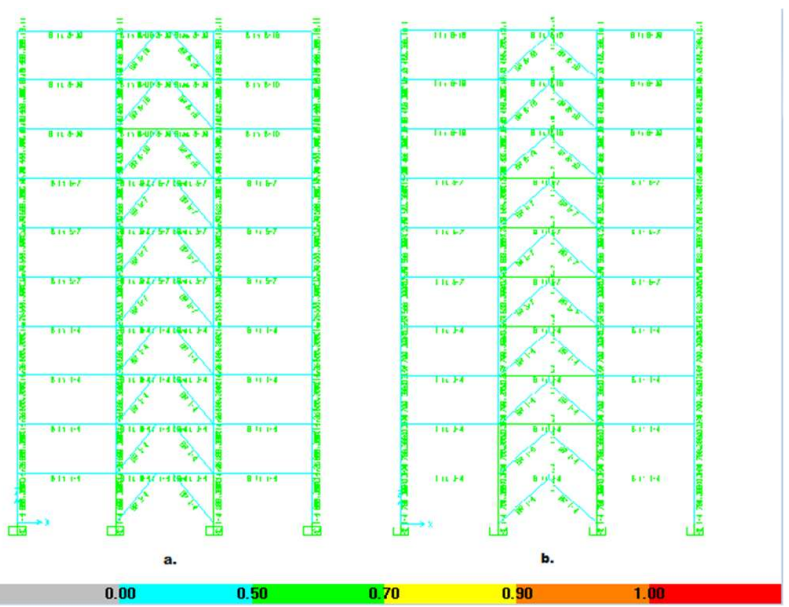

Gambar 14. Steel Check Design Pemodelan Makro; a. HEBF, b. V-EBF

Sumber: Hasil Analisis
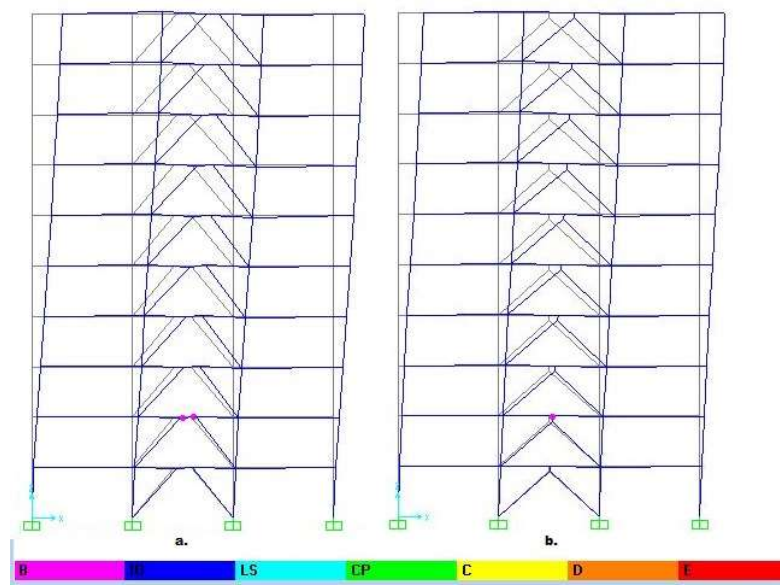

Gambar 15. Leleh Awal Push Over Pemodelan; a. H-EBF, b. V-EBF

Sumber: Hasil Analisis

Pelelehan pertama terjadi di elemen struktur link pada lantai 2. Simpangan pada kolom pada lantai paling atas adalah $66.92 \mathrm{~mm}$. Simpangan antar lantai pada kolom yang terdapat pada frame yang memiliki link leleh di lantai 2 adalah $6.6 \mathrm{~mm}$. mekanisme runtuh pada pemodelan rangka bresing eksentrik vertikal telah memenuhi syarat yaitu leleh pada link terlebih dahulu.

Pada pemodelan H-EBF pelehan mode akhir terjadi di elemen struktur link pada lantai 1-6, balok pada lantai 2 dan 3 , dan kolom pada lantai 1 pada frame rangka bresing eksentrik. Simpangan pada kolom pada lantai paling atas adalah $236.37 \mathrm{~mm}$. Simpangan antar lantai pada kolom 
yang terdapat pada frame yang memiliki link leleh di lantai 2 adalah $42.8 \mathrm{~mm}$.
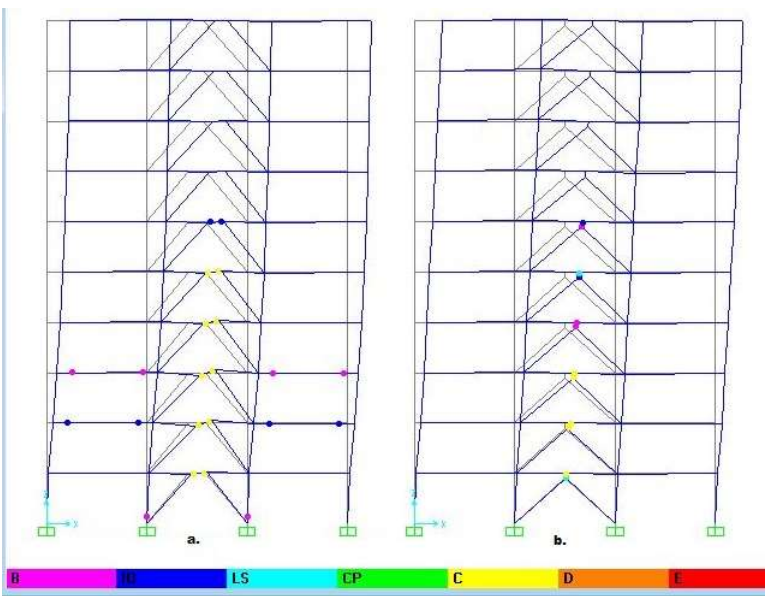

Gambar 16. Leleh Akhir Push Over Pemodelan Makro Sumber: Hasil Analisis

Pelelehan mode akhir terjadi di elemen struktur link pada lantai 1-6. Simpangan pada kolom pada lantai paling atas adalah $109.82 \mathrm{~mm}$. Simpangan antar lantai pada kolom yang terdapat pada frame yang memiliki link leleh di lantai 2 adalah $16.6 \mathrm{~mm}$. Pada pemodelan V-EBF terbentuknya sendi plastis hanya terjadi pada link. Untuk elemen struktur lainnya tidak terbentuk sendi plastis.

Pelehan mode akhir terjadi di elemen struktur link pada lantai 1-6. Simpangan pada kolom pada lantai paling atas adalah $109.82 \mathrm{~mm}$. Simpangan antar lantai pada kolom yang terdapat pada frame yang memiliki link leleh di lantai 2 adalah $16.6 \mathrm{~mm}$. Pada pemodelan V-EBF terbentuknya sendi plastis hanya terjadi pada link. Untuk elemen struktur lainnya tidak terbentuk sendi plastis.

Pada Tabel 5 dapat dijelaskan bahwa $\Delta$ Awal Leleh adalah deformasi pada struktur saat terjadi pada kolom bagian atas saat mode awal terjadinya sendi plastis seperti ditunjukkan pada Gambar 15. $\Delta$ leleh terakhir adalah deformasi pada kolom bagian atas struktur saat mode akhir terjadinya sendi plastis dalam analisa push over seperti yang ditunjukkan pada Gambar 16. Daktilitas diambil dari nilai $\Delta$ leleh terakhir dibagi dengan $\Delta$ Awal Leleh.

Tabel 5. Perbandingan Nilai Daktilitas H-EBF dan V-EBF pada Pemodelan Makro

\begin{tabular}{ccccc}
\hline Rangka & $\begin{array}{c}\Delta \text { Awal } \\
\text { Leleh } \\
(\mathrm{mm})\end{array}$ & $\begin{array}{c}\Delta \text { Leleh } \\
\text { Terakhir } \\
(\mathrm{mm})\end{array}$ & Daktilitas $\Delta$ & $\begin{array}{c}\text { Selisih } \\
(\%)\end{array}$ \\
\hline H-EBF & 121.03 & 236.38 & 1.953 & 15.97 \\
V-EBF & 66.92 & 109.83 & 1.641 & \\
\hline
\end{tabular}

Sumber: Hasil Analisis
Pola Keruntuhan pada V-EBF tidak menyebabkan struktur lainnya leleh. Sehingga V-EBF lebih mencegah kerusakan pada struktur lain. Sehingga lebih dimungkinkan saat melakukan rehabilitasi struktur setelah gempa terjadi. H-EBF memiliki nilai base shear sebesar 9543.826 KN lebih besar daripada V-EBF sebesar $6250.416 \mathrm{KN}$. Sehingga H-EBF lebih rentan terhadap beban gempa daripada V-EBF.

\section{b. Pemodelan Mikro}

Pada spesimen rangka bresing eksentrik link horizontal (H-EBF), elemen struktur link pada frame mencapai tegangan maksimum $250 \mathrm{MPa}$ saat deformasi portal kolom $8 \mathrm{~mm}$ seperti ditunjukkan pada Gambar 18 pada bagian atas kolom. Elemen balok, kolom, dan bresing belum mengalami pelelehan dengan tegangan maksimum yang terjadi adalah $229 \mathrm{MPa}$, Elemen link mencapai tegangan maksimum $250 \mathrm{MPa}$ seperti ditunjukkan pada Gambar 17, dimana sesuai dengan $f y$ material yang digunakan yaitu BJ41. Pada pola keruntuhan spesimen H-EBF telah sesuai dengan metodologi desain rangka bresing eksentrik, yaitu leleh pada link terlebih dahulu sehingga elemen struktur lain direncanakan mencapai tegangan leleh sesudah link mencapai tegangan maksimum $250 \mathrm{MPa}$. Setelah link mencapai tegangan maksimum $250 \mathrm{MPa}$ maka dilanjutkan pembebanan sampai link mengalami tegangan maksimum $410 \mathrm{MPa}$.

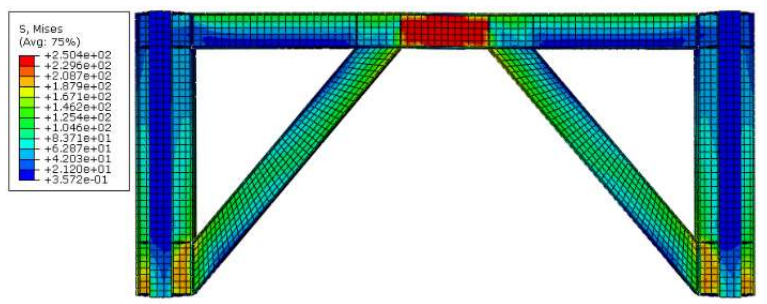

Gambar 17. Tegangan pada frame $\mathrm{H}-\mathrm{EBF}$ saat Link mencapai tegangan maksimum $250 \mathrm{MPa}$ Sumber: Hasil Analisis

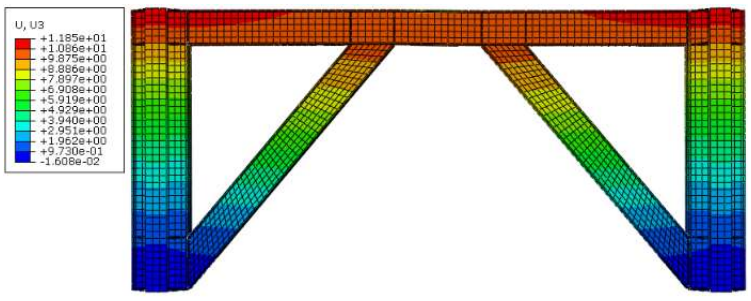

Gambar 18. Perpindahan Frame $\mathrm{H}-\mathrm{EBF}$ saat Link mencapai tegangan maksimum $250 \mathrm{MPa}$ Sumber: Hasil Analisis 


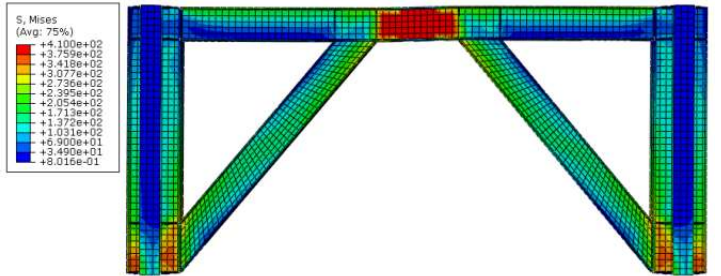

Gambar 19. Tegangan pada frame H-EBF saat Link Mencapai Tegangan Maksimum $410 \mathrm{MPa}$ Sumber: Hasil Analisis

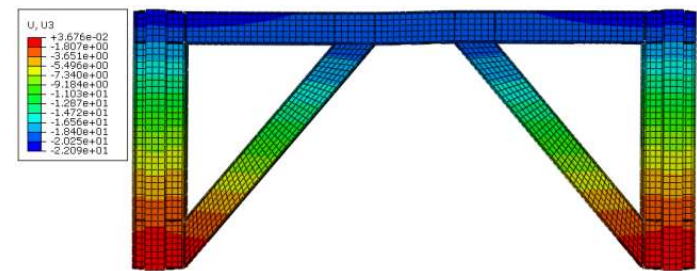

Gambar 20. Perpindahan Frame $\mathrm{H}-\mathrm{EBF}$ saat Link Mencapai Tegangan Maksimum $410 \mathrm{MPa}$

Sumber: Hasil Analisis

Pada spesimen rangka bresing eksentrik link horizontal (H-EBF), elemen struktur pada frame runtuh pada link pada deformasi portal $18.8 \mathrm{~mm}$ seperti ditunjukkan pada Gambar 19 pada bagian atas kolom. Elemen balok, kolom, dan bresing belum mengalami keruntuhan dengan tegangan maksimum yang terjadi adalah $375.9 \mathrm{MPa}$, elemen link mencapai tegangan maksimum $410 \mathrm{MPa}$ seperti ditunjukkan pada Gambar 20 dimana sesuai dengan fu material yang digunakan yaitu BJ-41. Pemodelan frame $\mathrm{H}-\mathrm{EBF}$ pada saat link mencapai $410 \mathrm{MPa}$, bagian link tidak mengalami putus. Pembebanan pada frame dijalankan sampai rotasi kolom mencapai 0.04 sesuai pada AISC loading protocol. Pada pola keruntuhan spesimen $\mathrm{H}-\mathrm{EBF}$ telah sesuai dengan metodologi desain rangka bresing eksentrik, yaitu leleh pada link terlebih dahulu.

Kurva histeresis pada Gambar 21 didapatkan dengan mengkombinasikan nilai reactional force (RF) pada dasar kolom frame dengan nilai displacement pada ujung kolom atas (U). Kondisi link mencapai tegangan maksimum 250 MPa pada saat rotasi kolom bernilai 0.0029. Kondisi link mencapai tegangan maksimum $410 \mathrm{MPa}$ saat rotasi kolom bernilai 0.00552 . Nilai rotasi tersebut didapatkan dari nilai defromasi yang dikonversi menjadi rotasi. Pada perpindahan sebesar $160 \mathrm{~mm}$ atau rotasi kolom sebesar 0.04 didapat reaksi dasar maksimum pada frame $\mathrm{H}$-EBF sebesar 5179.33 KN seperti ditunjukkan pada Gambar 21.

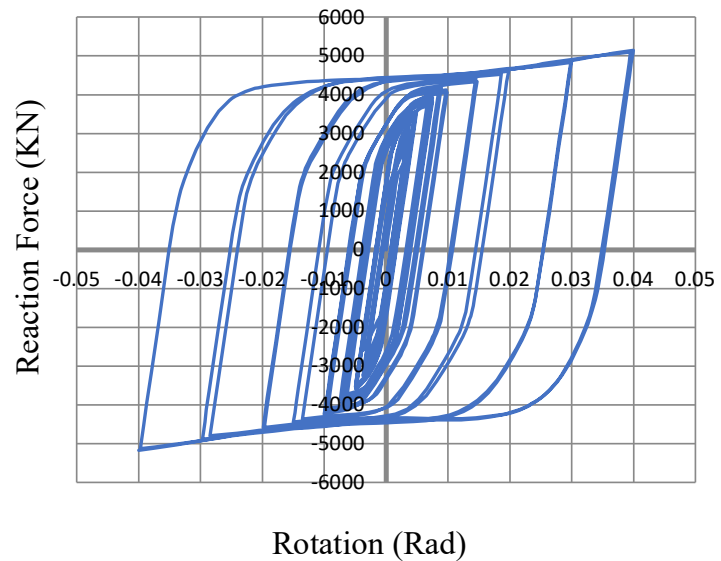

Gambar 21. Kurva Histeresis H-EBF Sumber: Hasil Analisis

Pada spesimen rangka bresing eksentrik link vertikal (VEBF), elemen struktur pada frame leleh pertama pada link pada deformasi portal $5.259 \mathrm{~mm}$ seperti ditunjukkan pada Gambar 23 pada bagian atas kolom. Elemen link mencapai tegangan $250 \mathrm{MPa}$, dimana sesuai dengan $f y$ material yang digunakan yaitu BJ-41 seperti ditunjukkan pada Gambar 22. Elemen struktur balok, kolom, dan bresing belum mengalami pelelehan dengan tegangan maksimum yang terjadi adalah 229.2 $\mathrm{MPa}$.

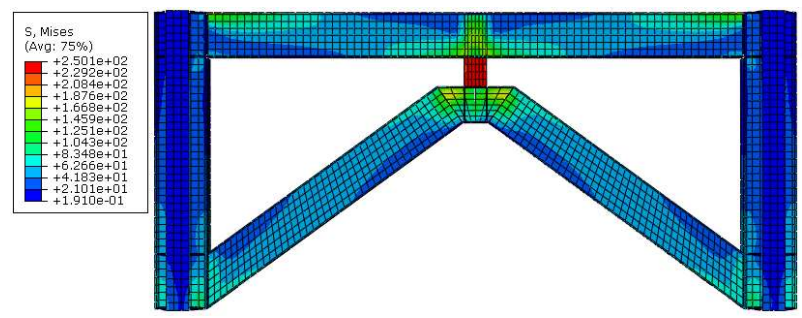

Gambar 22. Tegangan pada frame V-EBF saat Link mencapai tegangan maksimum $250 \mathrm{MPa}$ Sumber: Hasil Analisis

Pada pola keruntuhan spesimen V-EBF telah sesuai dengan metodologi desain rangka bresing eksentrik, yaitu leleh pada link terlebih dahulu.

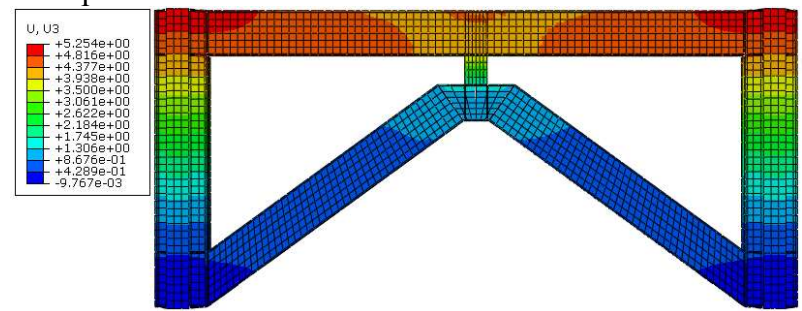

Gambar 23.Perpindahan Frame V-EBF saat link mencapai tegangan maksimum $250 \mathrm{MPa}$ Sumber: Hasil Analisis 
Pada spesimen rangka bresing eksentrik link vertikal (V$\mathrm{EBF}$ ), elemen struktur pada frame runtuh pada link pada deformasi portal $14.5 \mathrm{~mm}$ pada bagian atas kolom seperti ditunjukkan pada Gambar 25. Elemen balok, kolom, dan bresing belum mengalami keruntuhan dengan tegangan maksimum yang terjadi adalah $341.8 \mathrm{MPa}$. Elemen link mencapai tegangan maksimum $410 \mathrm{MPa}$, dimana sesuai dengan $f u$ material yang digunakan yaitu BJ-41 seperti ditunjukkan pada Gambar 24. Pemodelan frame V-EBF pada saat link mencapai $410 \mathrm{MPa}$, bagian link tidak mengalami putus. Pembebanan pada frame dijalankan sampai rotasi kolom mencapai 0.04 sesuai pada AISC loading protocol.

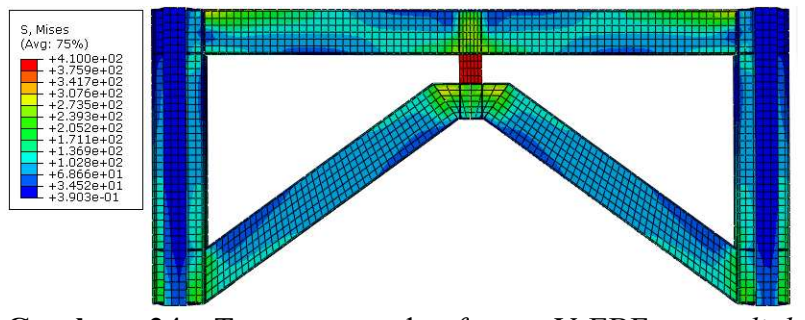

Gambar 24. Tegangan pada frame V-EBF saat link mencapai tegangan maksimum $410 \mathrm{MPa}$ Sumber: Hasil Analisis

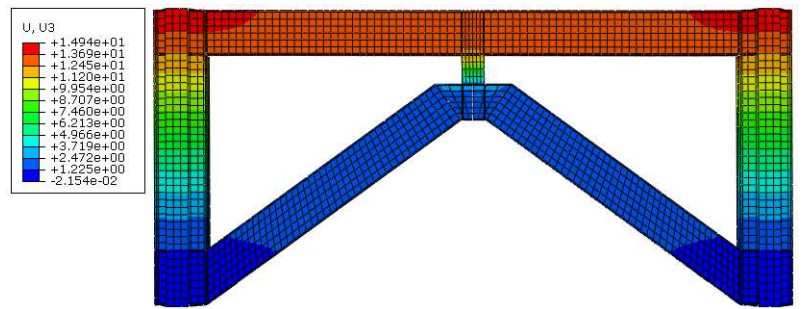

Gambar 25. Perpindahan Frame V-EBF saat link mencapai tegangan maksimum $410 \mathrm{MPa}$ Sumber: Hasil Analisis

Pada pola keruntuhan spesimen V-EBF telah sesuai dengan metodologi desain rangka bresing eksentrik, yaitu leleh pada link terlebih dahulu.

Kurva histeresis pada Gambar 26 didapatkan dengan mengkombinasikan nilai reaction force (RF) pada dasar kolom frame dengan nilai displacement pada ujung kolom atas (U). Elemen link mencapai tegangan maksimum 250 $\mathrm{MPa}$ saat rotasi kolom bernilai 0.0013 dan mencapai tegangan maksimum $410 \mathrm{MPa}$ saat rotasi 0.00373 . Nilai rotasi tersebut didapatkan dari deformasi yang dikonversikan menjadi rotasi. Pada perpindahan sebesar 160 $\mathrm{mm}$ atau rotasi kolom sebesar 0.04 didapat reaksi dasar maksimum pada frame V-EBF sebesar $4165.85 \mathrm{KN}$ seperti ditunjukkan pada Gambar 26.

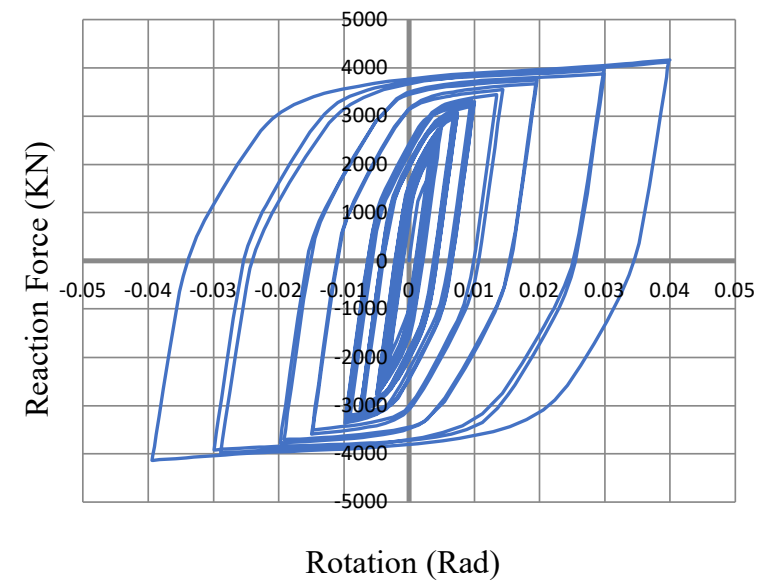

Gambar 26. Kurva Histeresis V-EBF Sumber: Hasil Analisis

Nilai reaction force maksimum saat rotasi kolom 0.04 pada spesimen H-EBF memiliki nilai lebih besar 1013.48 $\mathrm{KN}$ dibandingkan dengan spesimen V-EBF atau sebesar $19.57 \%$.

Tabel 6. Perbandingan Reaction Force maksimum H-EBF dan V-EBF saat rotasi kolom 0.04

\begin{tabular}{llc}
\hline Tipe Struktur & $\begin{array}{l}\text { Base Shear } \\
(\mathrm{KN})\end{array}$ & Selisih (\%) \\
\hline H-EBF & 5179.33 & 19.57 \\
V-EBF & 4165.85 & \\
\hline
\end{tabular}

Sumber: Hasil Analisis

Dari Tabel 6 dapat dijelaskan bahwa Reaction Force pada rangka bresing eksentrik horizontal (H-EBF) lebih besar dari rangka bresing horizontal tubular (V-EBF) karena pada pemodelan makro semakin bertambahnya berat pada struktur mengakibatkan bertambahnya reaksi dasar pada kolom.

Berdasarkan luasan kurva histeresis pada Gambar 27 didapatkan besar energi disipasi saat rotasi kolom 0.04 pada spesimen $\mathrm{H}-\mathrm{EBF}$ adalah 24641.10 $\mathrm{KNm}$, sedangkan pada spesimen V-EBF 1 energi disipasi didapatkan sebesar 19492.71KNm 


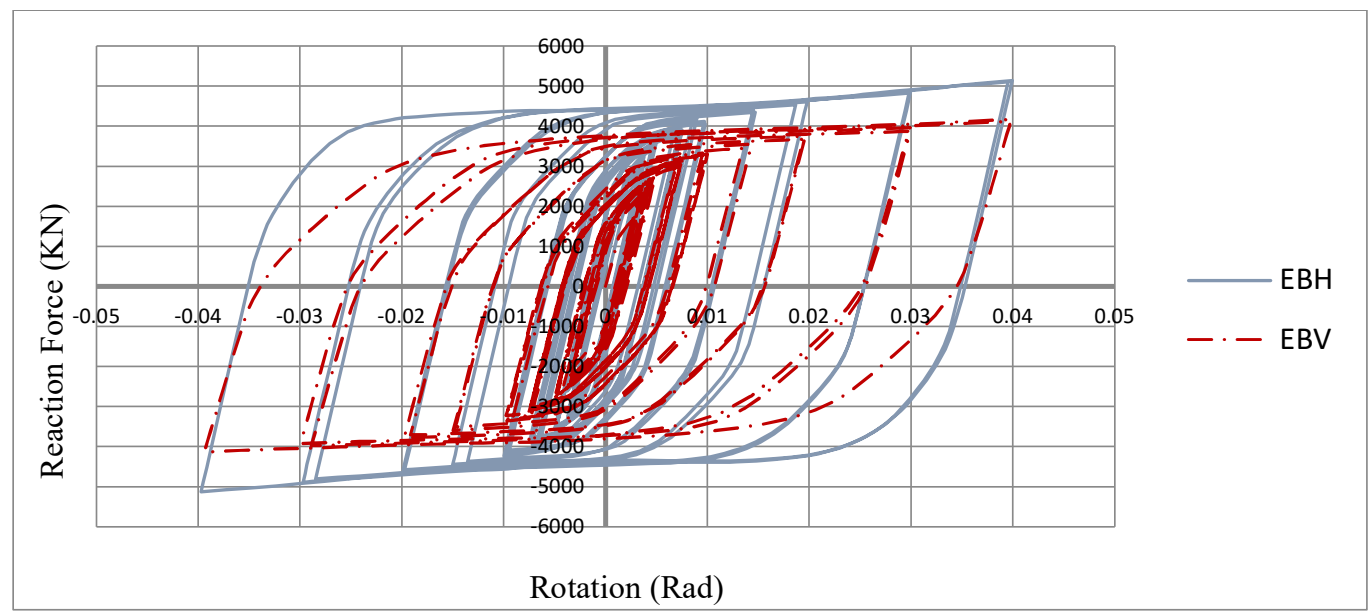

Gambar 27 Kurva Histeresis H-EBF dan V-EBF 1

Sumber: Hasil Analisis

Tabel 7. Perbandingan Deformasi frame H-EBF dan V-EBF Saat Link Mencapai Tegangan maksimum 250 Mpa dan maksimum $410 \mathrm{MPa}$

\begin{tabular}{lcccc}
\hline Spesimen & \multicolumn{2}{c}{ Deformasi } & \multicolumn{2}{c}{ Selisih (\%) } \\
\cline { 2 - 5 } & Link 250 & Link 410 & Link & Link 410 \\
& $\mathrm{MPa}$ & $\mathrm{MPa}$ & 250 & $\mathrm{MPa}$ \\
& $(\mathrm{mm})$ & $(\mathrm{mm})$ & $\mathrm{MPa}$ & \\
$\mathrm{H}-\mathrm{EBF}$ & 11.05 & 22.09 & 11.05 & 22.09 \\
V-EBF & 5.25 & 14.9 & & \\
\hline
\end{tabular}

Sumber: Hasil Analisis

Energi disipasi maksimum saat rotasi kolom 0.04 pada spesimen H-EBF lebih besar daripada spesimen V-EBF dengan selisih $5148.38 \mathrm{KNm}$ seperti ditunjukkan pada Tabel 8 atau sebesar $20.89 \%$.

Selisih perpindahan portal seperti ditunjukkan pada Tabel 7 saat link leleh yaitu $5.8 \mathrm{~mm}$ atau $11.05 \%$, saat link runtuh sebesar $7.19 \mathrm{~mm}$ atau $22.09 \%$.

Tabel 8. Perbandingan Energi Disipasi H-EBF dan V-EBF

\begin{tabular}{llc}
$\begin{array}{l}\text { Tipe } \\
\text { Struktur }\end{array}$ & $\begin{array}{l}\text { Energi Disipasi } \\
(\mathrm{KNm})\end{array}$ & Selisih (\%) \\
\hline H-EBF & 24641.10 & 20.89 \\
V-EBF & 19492.71 & \\
\hline
\end{tabular}

Sumber: Hasil Analisis

\section{Simpulan}

Berdasarkan hasil pemodelan makro dan mikro, maka didapatkan beberapa kesimpulan sebagai berikut:

1. V-EBF mempunyai berat struktur yang lebih ringan sebesar $34089,83 \mathrm{Kg}$ atau $0.88 \%$ dari berat H-EBF.

2. Saat pemodelan makro V-EBF memiliki nilai daktilitas lebih kecil daripada H-EBF dengan selisih 0.31 atau
$15.97 \%$ dari nilai daktilitas H-EBF. Sendi plastis pada V-EBF hanya terjadi pada link saja. Sehingga lebih baik dalam rehabilitasi gempa.

3. Saat pemodelan mikro, V-EBF memiliki perpindahan lantai lebih kecil daripada H-EBF dengan prosentase $11.05 \%$ saat link mencapai tegangan maksimum 250 $\mathrm{MPa}$ dan 22.09\% saat limk mencapai tegangan maksimum $410 \mathrm{MPa}$. Sehingga V-EBF memiliki kekakuan lebih besar daripada H-EBF.

4. V-EBF memiliki nilai base shear lebih kecil $19.57 \%$ daripada H-EBF. Energi disipasi pada V-EBF lebih kecil $20.89 \%$.

\section{Daftar Pustaka}

[1] J. W. Berman and M. Bruneau, "Tubular Links for Eccentrically Braced Frames . I : Finite Element Parametric Study," pp. 692-701, 2008.

[2] J. Bouwkamp, M. Ghasem, and A. Ghamari, "Case Studies in Structural Engineering An analytical model for inelastic cyclic response of eccentrically braced frame with vertical shear link ( V-EBF )," Tissue Cell, vol. 6, pp. 31-44, 2016.

[3] B. Suswanto, A. Rizki, E. Wahyuni, and J. Wilson, "Numerical Behavior Study of Short Link , Intermediate Link and Long Link in Eccentrically Braced Frame Steel Structure,” vol. 12, no. 21, pp. 11460-11471, 2017.

[4] P. W. Richards and C. Uang, "Testing Protocol for Short Links in Eccentrically Braced Frames," no. August, pp. 1183-1191, 2006.

[5] E. Mohammadrezapour and F. Danesh, "Experimental investigation of bolted link-to-column connections in eccentrically braced frames," $J$. 
Constr. Steel Res., vol. 147, pp. 236-246, 2018.

[6] AISC 341-10 - American Institute of Steel Construction, "Seismic Provisions for Structural Steel Buildings," Seism. Provisions Struct. Steel Build., no. 1, p. 402, 2010.

[7] T. Okazaki, M. D. Engelhardt, A. Drolias, E. Schell, J. Hong, and C. Uang, "Experimental investigation of link-to-column connections in eccentrically braced frames," J. Constr. Steel Res., vol. 65, no. 7, pp. 1401-1412, 2009.

[8] M. A. Musmar, "Effect Of Link On Eccentrically Braced Frames," vol. 40, no. 1, pp. 35-43, 2012.

[9] M. Ghasem, A. Ghamari, and J. Bouwkamp, "Investigating the nonlinear behavior of Eccentrically Braced Frame with vertical shear links ( V-EBF )," $J$. Build. Eng., vol. 10, no. February, pp. 47-59, 2017.

[10] M. Bosco and P. P. Rossi, "Seismic behaviour of eccentrically braced frames," Eng. Struct., vol. 31, no. 3, pp. 664-674, 2009.

[11] R. Montuori, E. Nastri, and V. Piluso, "Theory of plastic mechanism control for eccentrically braced frames with inverted y-scheme," JCSR, vol. 92, pp. 122-135, 2014.

[12] B. Suswanto, A. R. Amalia, E. Wahyuni, and N. Al Farisy, "Comparison of WF \& tubular links on the eccentrically brace frame system due to cyclic loads," Int. J. Adv. Sci. Eng. Inf. Technol., vol. 8, no. 3, pp. 799-804, 2018.

[13] John Barry Mander, "Seismic Design of Bridge Piers." University of Canterbury, 1983.

[14] M. A. Rofiq, H. Alrasyid, D. Iranata, and D. Irawan, "Prediksi Perilaku Lentur Kolom Beton Bertulang Mutu Tinggi Terhadap Kombinasi Beban Perpindahan Monotonik dan Aksial Rendah," vol. 16, pp. 43-50, 2019.

[15] B. Suswanto, J. Wilson, and W. Sutrisno, Sistem Struktur Eccentrically Braced Frames Teori Dasar dan Analisis Elemen Hingga. Surabaya, 2018. 
